\title{
The Perception of Customer Relationship Management Adoption Case of Mobile Companies in Saudi Arabia
}

\author{
Amine Nehari Talet, Mazen Harbi Shawosh and Saeed A. Al-Saeed \\ King Fahd University of Petroleum \& Minerals, Dhahran, Saudi Arabia
}

\begin{abstract}
The purpose of this study is to ascertain customer satisfaction perception of Customer Relationship Management (CRM) adoption by mobile telecom companies in Saudi Arabia. This study surveys more than 440 mobile telecom customers to investigate their opinion about the quality of offered customer services by mobile telecom companies and its impact on customer satisfaction and hence customer. The study concentrates on the main three channels used by mobile companies to provide customer services (customer service offices, phone operator and web site services). Empirical findings present evidence that the quality of customer service significantly affect customer satisfaction and thus customer loyalty. It is found that the majority of customers preferred to use phone operator than office customer services.
\end{abstract}

Keywords: Customer Relationship Management (CRM), Customer Satisfaction, Customer loyalty.

\section{Introduction}

In today's globalised and borderless market, quality, productivity and satisfaction of customers pose a challenge for the survival and growth of all firms. These growth and survival demands are further expanded by the need to attract and retain loyal customers. The management recognizes that customers are the spirit of a business and that a company's success depends on effectively managing relationships with them. Thus, the customer is the main focus for any successful business. Business success depends on a firm's understanding and meeting customers' needs and demands. Today, often, the objectives become constraints for businesses and their employees when they do not have appropriate tools, equipment, or methods to achieve this goal. Since the last two decades, the telecommunications sector has become a vital key area for the economic development of nations. The telecommunication industry's role in an economy cannot be underemphasized. This is because it is the means through which all daily transactions and activities are undertaken. It aids decision making, organizing, influencing, activating, instructing, providing feedback, promoting interpersonal and business relationships as well as exchange of information. All social, economic, political, cultural, trade and commercial activities are undertaken using telecommunication. One important service in an economy is telecommunication. The nature of a country's telecommunication industry affects its pace of commercial and domestic activities. Due to the poor performance of many of these telecommunication firms, particularly in the developing countries, governments have had to intervene.

Copyright (c) 2011 Amine Nehari Talet, Mazen Harbi Shawosh and Saeed A. Al-Saeed . This is an open access article distributed under the Creative Commons Attribution License unported 3.0, which permits unrestricted use, distribution, and reproduction in any medium, provided that original work is properly cited. Contact author: Amine Nehari Talet E-mail: nehari@kfupm.edu.sa 
It is well known that it costs more for organizations to attract new customers compared to retaining existing ones (Hsieh, 2009). Also, the role 80/ 20 indicates that you make an eighty percent benefit from a twenty percent customer (Galitsky, \& de la Rosa, 2011). With this in mind, information technologies (IT) can be used to establish strong and profitable long-term relationships with customers.

(Babu, \& Kumar, 2010; Agrawal, \& Berg, 2009; Hsieh, 2009). This means that by creating long-term relationship with loyal customers, you will ensure long-term success (Boohene, \& Agyapong, 2011; Kuusik, \& Varblane, 2009).

Long- term relationships can be attained by delivering the right products and services to customers. The delivery of these products and services and the means used for this delivery are also important (Hsieh, 2009). Changing to customer-centric means that organizations must build up ways of gathering data about customers and obtain the needed tools to satisfy the desires of their customers (Mendoza et al., 2007). Customers' preferences and perceptions are changing (Agrawal, \& Berg, 2009); and customers are the ones who initiate transactions (Babu, \& Kumar, 2010). Customers' awareness increased due to several factors including IT development and boundless competition from all around the world (Kuusik, \& Varblane, 2009).

CRM becomes more and more important to organizations with fierce competition over customers (Mendoza et al., 2007). CRM helps organizations understand their customers' requirements, and it is considered a tool for improving the competitive advantage (Lin et al, 2010; Agrawal, \& Berg, 2009) and to enhance innovation capabilities (Lin et al., 2010). CRM also helps organizations become more effective and efficient when dealing with customers (Beldi et al., 2010). With CRM, organizations can increase profitability and also boost customer loyalty and satisfaction (Pezeshki et al., 2009).
Nowadays, technology provides businesses with systems that can help companies track customer interaction with firms and allow employees to quickly retrieve all information about the customers. This concept is called a customer relationship management (CRM) system and if used properly, it could enhance a company's ability to achieve the ultimate goal of retaining customers and so gain a strategic advantage over its competitors.

\section{Literature Review}

Customer loyalty has been found in literature to be a competitive tool for many companies. This is even much more pronounced in today's highly globalised, industrialized and competitive markets. The growth and survival of companies depend on how loyal their customers are of which telecommunication is no exception. Various studies have been carried out in the developed countries regarding customer loyalty (Ndubusi et al, 2007; Khatibi et al., 2002; Uncles et al 2003). However, only few studies have been carried out in this area in the developing world, especially in the telecom sub-sector.

Lack of practical tools and methodologies, which guarantee managers a better consideration of customer needs and expectations, can avoid the misuse of scarce available resources.

The concept of the vendors-customers relationships, named "relationship marketing", has evolved from the idea that there is a variety of customer relationships ranging from transactional to relational dealings. Today, most companies seek to create total or cumulative customer satisfaction as opposed to transactionspecific customer satisfaction. Customer satisfaction and the quality of customer service are particularly considered significant in building trustworthy relationships with customers and retaining the competitive advantage. As a result, customer relationship management (CRM) systems and customer experience 
management (CEM) have become a musthave set of tools and techniques in the past decade. Sophisticated organizations worldwide rely on specialized CRM software systems to accumulate and analyze customer-focused information.

IT is an enabler for enhanced customer relationships in various ways-- it gives firms the ability to deploy strategies by customizing individual customer relationships utilizing customer databases, interactive and mass customization technologies (Verhoef and Donkers, 2001).

CRM was principally evolved by marketing (Kotler, 1997) and was started by a deep analysis of consumer behavior. As the concept of CRM matures, CRM definitions also change to reflect evolutions to CRM. Some of CRM definitions come from technological perspective while others come from business perspective.

\section{CRM from Business Perspective}

CRM refers to activities that manufacturers practice for understanding customer demands and improving customer satisfaction (Aggarwal, 1997). CRM involves acquisition, analysis and use of knowledge about customers in order to sell more goods or services and to do it more efficiently. Oracle Corporation on the other hand refers to CRM as about knowing your customers better and effectively using that knowledge to own their total experience with your business and to drive revenue growth and profitability. Others defines CRM as a management approach that involves identifying, attracting, developing and maintaining successful customer relationships over time in order to increase retention of profitable customers (Bradshaw and Brash, 2001; Massey et al., 2001). Also, Sin et al. (2005) refers to CRM as utilizing extensive strategies and engineering to find, obtain and cultivate advantaged customers, and hence maintain long-term partnerships. Likewise, CRM is defined as a process/application that permits organizations to gather and analyze customer data rapidly while seeking to improve customer loyalty via targeted products and services (Rigby et al., 2002).Similarly, Swift (2001) defines it as a process designed to collect data related to customers, to grasp features of customers and to apply those features in particular marketing activities.

Winer (2001) considers CRM a set of strategies and tools aimed at retaining customers over time instead of attracting new ones. It needs some basic components, from a database to basic analyses to be developed on it, from decisions about customers. In fact, he considered that one of the research priorities in the CRM field is the development of metrics that enable the managers to know to what extent CRM programs are working. However, Bose, (2002) refers to CRM as to involve acquisition, analysis and use of knowledge about customers in order to sell more goods or services and to do it more effectively, and $\mathrm{CRM}$ as a revolving process in which firms interact with their customers thereby generating, aggregating and analyzing customer data and employing the results for service and marketing activities (Schoder and Madeja, 2004).

In marketing literature, CRM has been placed in the overall context of marketing thought and especially that of relationship marketing strategies as "an ongoing process that involves the development and leveraging of market intelligence for the purpose of building and maintaining a profitmaximizing portfolio of customer relationships" (Zablah et al., 2004).

While technology is a key enabler, it is only a means to an end and most authors view CRM as a combination of strategy and information systems focusing companys' attention on customers in order to serve them better (Chan, 2005).

CRM is aimed at unifying the potential of relationship marketing strategies and IT to 
create profitable, long-term relationships with customers and other key stakeholders. Furthermore, CRM provides enhanced opportunities to use data and information to understand customers and correlation value with them. This requires a cross-functional integration of processes, people, operations and marketing capabilities that is enabled through information, technology and applications (Payne and Frow, 2005).Others saw CRM as a complex set of interactive processes that aims to achieve an optimum balance between corporate investments and fulfilling customer needs in order to generate maximum profit. (Ragnar, Lutz and Walter, 2007)

Strategically, CRM views customer relationships as an investment that will contribute to the enterprise's bottom line. Customer relationships' design and management are aimed at strengthening an enterprise's competitive position by increasing customers loyalty. While this extends beyond the use of IT, IT is still an important enabler of modern CRM (Ragnar,et al, 2007).

CRM as a philosophy: authors taking up this approach consider CRM to be a complex strategy involving all the corporate organizing structure in order to strengthen the relationship with the client; they avoid considering CRM only as an instrument of data collection. So, they all agree that CRM is a corporate strategy and a systematic approach based on relational marketing that has the aim to select and manage clients in order to optimize their value in the long run and to, consequently, maximize value creation for the enterprise (Valsecchi and Rangone, 2007).

\section{CRM from Technological Perspective}

CRM can be interpreted as an integration of technologies and business processes used to satisfy the needs of a customer during any given interaction. Also, CRM is basically an enterprise-wide integration of technologies working together such as data warehouse, web site and intranet/ extranet, phone support systems, accounting, sales, marketing and production (Bose, 2002). Nguyen et al. (2007) interpreted CRM as a process of digitizing a staff's knowledge about their customers.

Precise customer data is an essential input to successful CRM performance (Abbott et al., 2001) and, therefore, technology plays an important role in CRM in adding to organization intelligence (Boyle, 2004). In fact, amazing advances in IT provide organizations with the tools to collect, store, analyze and share customer information in ways that greatly improve their capability to respond to the needs of individual customers and hence to attract and retain customers (Butler, 2000). The approach of one-to-one relationships, customer-value analysis and mass customization (Hart, 1995) are now part of the reality through unparalleled advances in IT, transforming the traditional approach to CRM to an integrated webenabled approach, equipped by tools such as customer information systems, automation of customer support processes and call centers (Ghodeswar, 2001). CRM calls for "information-intensive strategies" which utilize computer technologies in establishing relationships, improving existing technology and thoroughly linking technology positioning to desired business initiatives (Harding et al. 2004). Computer technologies such as computer-aided design/manufacturing, flexible manufacturing systems, just-in-time production databases, data warehouses, data mining and CRM software systems enable organizations to deliver greater customization with better quality at lower cost. It also helps staff at all contact points serve customers better. Many customercentric activities would be impossible without appropriate technology (Leo, 2005).

\section{Telecommunications Sector in Saudi Arabia}

Mobile communications markets can be divided by the type of services provided and 
by the telecommunications networks used for production into the sub-markets for cellular radiotelephony, paging, trunked mobile radio access and satellite services and networks (Gerpott, 1998, Knauer, 1998).

Saudi Arabian telecommunications sector is considered one of the biggest in the Middle East and North Africa (MENA) region. Saudi Arabia has four mobile telecommunication companies. They are, Saudi Telecommunication Company (STC), Mobily, Zain and Bravo. Saudi Arabia Telecommunications Report (2011), published by Business Monitor International, shows that the number of mobile phone subscribers in 2008 was $35,593,000$ subscriptions, compared to $44,800,000$ subscriptions in 2009. The report also forecasts the number of mobile subscriptions for the next five years, where it is expected to reach around 60,349,000 subscriptions in 2015. The report also provides the market share of each mobile company in the Kingdom. STC's market share for the $3^{\text {rd }}$ quarter of 2010 is around 43\%, Mobily's share is $41 \%$, Zain with market share of around $15 \%$, and Bravo only contributes with $5 \%$ to the Saudi mobile market share.

The telecom market in Saudi Arabia is growing rapidly. In fact, mobile companies' revenues have been increasing as a cumulative average rate of $15 \%$ annually, growing from SR 19.8 billion (US\$ 5.28 billion) in 2001 to SR 52.5 billion (US \$14 billion) in 2009. Mobile services revenues represent about $77 \%$ of the total telecom market revenues in Saudi Arabia.

\section{History}

Saudi Arabia privatized telecom section in 1998. Then later in 2001, Saudi government, in preparation for opening the telecom market for competition, established the regulation authority for the telecom sector market and called it Communication and Information Technology Commission (CITC). Saudi Arabia opened its telecom market for competition in 2005. The second mobile telecom service provider, Etihad Etisalat (Mobily), was licensed to work in Saudi Arabia. Two years later, the third mobile company Zain was licensed. Telecom section in Saudi Arabia consists of three distinctive services: fixed telephone service, mobile phone service and internet services.

\section{Mobile Sector}

Mobile customers have grown from less than 20 million customers in 2005 to 42 million customers in 2009 representing a 43\% annual growth. In 2007 only (when the 3rd mobile service started), a total of 8.72 million customers were added to the market which represents the largest growth in one year throughout Saudi telecom history. The total number of mobile subscriptions grew to around 53.3 million by end of Q1 2011, with penetration stood at 191\%. Prepaid subscriptions constitute the majority (87\%) of all mobile subscriptions, in line with the trend in other similar markets around the world.( CITC 2011)

\section{Fixed Line Sector}

Fixed telephone lines have grown on a steady basis from 3.2 million lines in 2001 to 4.52 million in 2011 in which 3.34 million lines (73\%) are residential lines. This represents a household teledensity of around 67\%, while the population teledensity is around $15.9 \%$ or 159 telephone lines for every 1000 inhabitants. (CITC 2011)

\section{Internet Services}

On the other hand, internet users in Saudi Arabia have increased from just 1 million in 2001 to nearly 13 million in 2011. This represents a cumulative average growth rate of about 33\% per year. Internet penetration is estimated at $46 \%$ of population in 2011 . This rapid growth of the number of users is attributed to dramatic declining in computer prices, internet access prices in addition to increased awareness of the public and the increase of local contents in Arabic language 
and the availability of eServices such as EBanking. (CITC 2011).

\section{Broadband Service}

A. Fixed Broadband subscriptions including the (DSL) subscriptions, Fixed Wireless (Wimax) subscriptions and other fixed lines have grown to around 2.13 millions subscriptions at the end of 9M 2011. The Fixed Broadband penetration rate stood at around $30.6 \%$ of household at the end of $9 \mathrm{M}$ 2011.

The liberalization of the telecom sector and the resulting competition in the market has led to remarkable benefits for the Saudi economy at large and for the consumers in particular, such as better quality services, improved customer care, more consumer choices and lower prices. While the cost of living index continued to rise in the last few years due to increased prices of most of its components, the prices progressively decreased (CITC 2011).

B. Mobile Broadband The total subscriptions to mobile broadband reached 11.5 million at the end of $9 \mathrm{M}$ 2011, representing a penetration of $40.5 \%$ of the population. The mobile broadband market continues to gain momentum in the Kingdom and is becoming an increasingly exciting market. One of the key reasons for this growth is the fact that due to competition and the huge expansion of the smart phones which enable customers for varieties of data packages. Becoming easier to access via mobile devices such as smart phones, mobile networks are also improving as 3.5G (HSPA) continues to be deployed and wireless broadband technologies (4G) emerge over the next few years. (CITC 2011).

\section{Improving Customer Services in Saudi Market}

Since the start of competition in 2005, customers of telecom services in Saudi noticed great improvement in the level of services provided by Saudi Telecom
Company (STC). STC also worked hard to improve its customer services level to compete in the market. Because STC inherited most of its employees from the governmental sector, it was very challenging to change its culture from a government style to a profit- oriented organization. The company had to go over several strategic shifts to incorporate customer satisfaction into its internal culture. Yet, our study shows that there is more to do to improve customer satisfaction.

\section{Research Methodology}

\section{Sample}

A questionnaire was distributed to 600 individuals and also published online. For the hard copy questionnaire, a cover letter explaining the purpose of the study was enclosed. For the online version, the letter was placed in the first page of the questionnaire. Out of the distributed ones, 90 were received; 80 of them being usable in addition to 361 completed online surveys out of 480 online attempts. The total number of usable questionnaires for analysis is 441 surveys.

\section{Data Collection}

We accept the fact that not all relevant variables can be studied simultaneously and/ or controlled precisely. We also understand that our assumption may allow us to notice some relevance and may also prevent us from noticing others.

In order to confirm that selected variables for this study are relevant to respondents (mobile telecom customers in Saudi Arabia), a pilot study has been conducted before finalizing the questionnaire.

The final developed questionnaire is divided into four parts. The first part contains demographic questions such as gender, age and education level. The second part contains general information about respondent's mobile service usage. The third part 
measures respondent's usage and satisfaction about mobile services as well as customer service channels. The last part assesses overall customer satisfaction and loyalty. Some of these variables are selected from previous studies.

The constructs in the questionnaire use a five point Likert-type scale where 1=strongly agree, and 5 strongly disagree.

\section{Reliability Analysis}

The construct is tested against the scale reliability function on SPSS 19.0 using the Cronbach's Alpha in order to evaluate the internal consistency of the studies constructs. Cronbach's Alpha coefficient value for the first construct is 0.898 and for the second construct is 0.806 . Both values exceeded 0.7 suggested by Nunnally (1975). The coefficient values suggest that both constructs are internally consistent and reliable.

\section{Research Variables}

\section{Customer Satisfaction Construct}

\section{a) Independent Variables}

To compute the first independent variable, respondents were asked to express their opinion on the following factors using a five point scale:

- The ease and speed of getting connected to the support phone operator (X1).

- The level of operator attitude (X2).

- Knowledge of operator (X3).

- The speed of operator in providing problem solution (X4).

- The follow up action on unresolved problems (X5).

- The ease of site navigation (X6).
- The responsiveness of web site (X7).

- The site availability and problem free (X8).

- The ease and speed of reaching one of office customer support staff (X9).

- Knowledge of office support staff(X10).

- How good the office staff in following up problems that need further action (X11).

- How serious and professional the service provider is in handling complaints (X12).

- Responsiveness of the service provider to complaints (X13).

- Speed of resolving reported issues/ problems (X14).

- Overall staff good knowledge about reported issues/ problems (X15).

An aggregate score for perceived service quality was computed from the above 15 factors and labeled as XServQual for consequent analysts.

\section{b) Dependent Variable}

The dependent variable of this construct is overall satisfaction with mobile service provider.

\section{Customer Loyalty Construct}

\section{a) Independent Variables}

- Overall satisfaction with customer call center (X1).

- Overall satisfaction with customer service Office (X2).

- How service provider strives to gain high customer satisfaction (X3)

- Overall satisfaction with this service provider (X4)

An aggregate score for customer satisfaction was computed based on the above 4 factors 
and labeled as XOverallSatis for consequent analysts.

\section{b) Dependent Variable}

The dependent variable of this construct is customer loyalty to their mobile service provider.

\section{Research Results and Discussion}

In this part of the analysis, we discuss demographic information of the respondents.
Table no. 1 shows that about $89.3 \%$ are males. Ages ranged from below 18 to 64 years where $40 \%$ are between 25 and 34 years old and 39\% are between 18-24 years old. $14 \%$ of participants' ages are between 35 and 44 years old. From educational perspective, more than $66 \%$ of participants hold BS degree. $16 \%$ hold higher education degree and $15.9 \%$ hold high school degree. On the other hand, $90 \%$ of participants are Saudi citizens.

Table 1: Demographic Details

\begin{tabular}{|llll|}
\hline Demographic & Characteristics & Frequency & Percentage \\
\hline \multirow{4}{*}{ Age } & Male & 394 & 89.3 \\
\cline { 2 - 4 } & Female & 47 & 10.7 \\
\cline { 2 - 4 } & Younger than 18 years & 8 & 1.4 \\
\cline { 2 - 4 } & 18-24 years & 171 & 38.8 \\
\cline { 2 - 4 } & 25-34 years & 179 & 40.6 \\
\cline { 2 - 4 } & 35-44 years & 63 & 14.3 \\
\cline { 2 - 4 } Education & 55-54 years & 18 & 4.1 \\
\cline { 2 - 4 } & B5-64 years & 4 & 0.9 \\
\cline { 2 - 4 } & Below high school & 6 & 1.4 \\
\cline { 2 - 4 } & BS & 70 & 15.9 \\
\cline { 2 - 4 } Nationality school & High education & 71 & 66.7 \\
\cline { 2 - 4 } & Saudi & 397 & 16.1 \\
\cline { 2 - 4 } & None-Saudi & 44 & 10 \\
\hline
\end{tabular}

\section{Participant's Mobile Carrier Distribution}

As detailed in table 2, among participants, $61 \%$ are customers of Saudi Telecom Company, whereas $32.8 \%$ are Mobily customers. Zain customers are estimated at $6.12 \%$ of participants. This distribution suggests that STC serves about $61 \%$ of mobile customers in Saudi Arabia, Mobily serves about $33 \%$ of customers in Saudi Arabia and Zain serves the rest. From plan type perspective, among STC participated customers, $77.3 \%$ are postpaid plan customers and the rest are prepaid plan customers. Mobile customers in contrast consist of $72.4 \%$ postpaid customers and the rest are prepaid. As to Zain customers, there are $52 \%$ postpaid while $48 \%$ are prepaid.
Telecom companies regard postpaid customers as long-term relationship customers, whereas prepaid customers as short term ones. However, prepaid customers yield highest profits due to the nature of prepaid plan prices where they tend to be more expensive with expiry dates. Companies fight to attract postpaid customers as they provide stable and predictable income source for companies. On the other hand, Communications and Information Technology Commission (IITC) Saudi communications authority- allows customers to transfer their mobile service numbers to any of the two mobile telecom companies in the Saudi Market. It is worth mentioning that the survey shows that customers to recent established companies 
have prepaid plans compared to wellestablished companies. For instance, 77.3\% of STC customers who participated in the survey were postpaid compared to $51.9 \%$ of Zain customers.

Table 2: Participant's Mobile Carriers

\begin{tabular}{|lllcc|cr|}
\hline Company & Participants & Percentage & Prepaid plan & & \multicolumn{2}{c|}{ Postpaid plan } \\
\hline STC & 269 & $61.00 \%$ & 61 & $22.7 \%$ & 208 & $77.3 \%$ \\
\hline Mobily & 145 & $32.88 \%$ & 40 & $27.6 \%$ & 105 & $72.4 \%$ \\
\hline Zain & 27 & $6.12 \%$ & 13 & $48.1 \%$ & 14 & $51.9 \%$ \\
\hline & & Totals & $\mathbf{1 1 4}$ & $\mathbf{2 5 . 9 \%}$ & $\mathbf{3 2 7}$ & $\mathbf{7 4 . 1 \%}$ \\
\hline
\end{tabular}

\section{Participants Geographical Distribution}

Survey participants are distributed across major Saudi Arabian regions. Table 3 shows about $47 \%$ per cent are from central region where country capital, Riyadh, is situated. $40 \%$ are from eastern region and $7.5 \%$ from the western region. The rest is different places including people currently out of Saudi Arabia such as students.

Table 3: Participants Geographical Distribution

\begin{tabular}{|ccc|}
\hline Region & Frequency & Percentage \\
\hline Western & 33 & $7.48 \%$ \\
\hline Central & 207 & $46.94 \%$ \\
\hline Eastern & 177 & $40.14 \%$ \\
\hline Others & 24 & $5.44 \%$ \\
\hline
\end{tabular}

Customers Preference of Service Channels Provided by Mobile Companies

Table 4 shows customer's preferences of available channels to request services and/ or modify services. More than $70 \%$ of customers across the entire mobile companies call company operator for service- related issues or requests. Also, 40\% of STC customers,
$44 \%$ of Mobily customers and only $14 \%$ of Zain customers call into the automated service to get desired service. About $41 \%$ of STC customers, $44 \%$ of Mobily customers and $48 \%$ of Zain customers use company web site to get desired service. Percentages of customers using different channels are quite similar across all companies except in Zain self-service.

Table 4: Customers Loyalty and Satisfaction

\begin{tabular}{|ccccc|}
\hline Company & $\begin{array}{c}\text { Overall } \\
\text { Satisfaction }\end{array}$ & STD Div. & $\begin{array}{c}\text { Customer } \\
\text { Loyalty }\end{array}$ & STD Div. \\
\hline STC & 2.66 & 1.26 & 2.41 & 1.01 \\
\hline Mobily & $\mathbf{3 . 5 2}$ & $\mathbf{1 . 0 6}$ & $\mathbf{3 . 4 0}$ & $\mathbf{1 . 0 1}$ \\
\hline Zain & 3.28 & 1.36 & 3.23 & 0.95 \\
\hline
\end{tabular}




\section{Mobile Companies Performance}

As seen in our study, providing quality customer service leads to customer satisfaction. Satisfaction in turn leads to customer loyalty. In other words, quality customer service leads to customer loyalty and hopefully customer retention. Customer Relationship Management (CRM) plays a vital role in interacting with customers. Ten questions are included to measure customers' satisfaction and loyalty. The following table shows the average rates for each company from customer satisfaction and loyalty perspectives. Table 4 shows customer satisfaction and customer loyalty for the three mobile telecom companies in Saudi Arabia. Numbers are generated by assigning a 5 scale measure-- 5 for strongly agree, 4 for agree, 3 for neutral, 2 for disagree and 1 for strongly disagree. All customer evaluation scores are added together for each factor and then divided by the number of participants of each company to get average customer responses for each company. Standard deviation is calculated for both indicators and all have reasonable variation. Mobily, for instance, scores a higher average customer satisfaction rate (3.52 out of 5) and also a high customer loyalty rate as well (3.4 out of 5). Zain comes in the second position with 3.8 out of 5 for customer satisfaction and 3.23 out of 5 for customer loyalty. STC comes in the last position with 2.66 out of 5 for customer satisfaction and 2.41 out of 5 for customer loyalty.

To measure customer perception about companies CRM performance (table 5), we developed a formula to calculate average customer evaluation for CRM implementation in each mobile telecom company based on the last question in our survey (How do you evaluate the overall customer relationship management carried out by your mobile service provider?). This question has 3 choice-answer-- excellent, fair and poor. Each of the three companies got 3 points for each excellent rating, 2 for each fair rating and 1 for each poor rating. We then added ratings for each company and then divided the total points by the number of participants for each company and represented the ration in percentage value in the table. Standard deviation is calculated to ensure reasonable variation. Also, table no. 5 shows percentages of customers' ratings for each mobile telecom company. For instance, $50 \%$ of Mobily customers rated Mobily as excellent in CRM whereas only $11.9 \%$ of STC customers rated it as excellent in CRM.

Table 5: Customers Overall Rating for CRM

\begin{tabular}{|ll|ccccc|}
\hline Company & participants & Excellent & Fair & Poor & W. Average & StdDiv \\
\hline STC & $\mathbf{2 6 9}$ & $\mathbf{1 1 . 9 0 \%}$ & $\mathbf{5 5 . 3 9 \%}$ & $\mathbf{3 2 . 7 1 \%}$ & $\mathbf{5 9 . 7 3 \%}$ & $\mathbf{0 . 6 3}$ \\
\hline Mobily & $\mathbf{1 4 5}$ & $\mathbf{5 0 . 3 4 \%}$ & $\mathbf{4 0 . 0 0 \%}$ & $\mathbf{9 . 6 6 \%}$ & $\mathbf{8 0 . 2 3 \%}$ & $\mathbf{0 . 6 6}$ \\
\hline Zain & $\mathbf{2 7}$ & $\mathbf{3 7 . 0 4 \%}$ & $\mathbf{4 4 . 4 4 \%}$ & $\mathbf{1 8 . 5 2 \%}$ & $\mathbf{7 2 . 8 4 \%}$ & $\mathbf{0 . 7 2}$ \\
\hline
\end{tabular}

Conclusion

The results for this study show that perceived quality of service for customer service channels offered by mobile telecom companies in Saudi Arabia yield the most influence to customer satisfaction. Furthermore, we have seen that improvement of such customer service provides the highest customer satisfaction in return. CRM certainly plays a major role in providing required information to customers through phone in a timely manner and helps to track customer concerns to maximize satisfaction levels. Also, improving customer services should lead to customer loyalty. Since customer loyalty is influenced by customer satisfaction variation, there are other factors that might affect customer loyalty beyond customer satisfaction factor. This might be an interesting subject to address in further studies. A further study 
needs to be carried out to investigate root causes according to service provider perspective such as CRM implementation, internal processes and related factors. Also, it might be interesting to find out the reason why would Mobily for instance outperform STC who has been in the market for much longer time and with much more capabilities and yet, in a few years Mobily was able to capture a considerable percentage of market share.

\section{References}

Abbott, J., Stone, M. \& Buttle, F. (2001). "Customer Relationship Management in Practice - a Qualitative Study," Journal of Database Marketing , 9(1), 24-34.

Aggarwal, S. (1997). 'Flexibility Management: the Ultimate Strategy,' Industrial Management, Vol. 39 No. 1, Pp. 5-14.

Agrawal, G. K. \& Berg, D. (2009). "The Development of Services in Customer Relationship Management (CRM) Environment from 'Technology' Perspective," Journal of Service Science and Management, 2(4), 432-438.

Babu, K. \& Kumar, B. (2010). 'Customer Service Management - Turning Customer Loyalty into Profitability,' Synergy, 8(2): 9398.

Beldi, A., Cheffi, W. \& Day, P. K. (2010). "Managing Customer Relationship Management Projects: the Case of a Large French Telecommunications Company," International Journal of Project Management 28(4): 339-351.

Boohene, R \& Agyapong, G. K. Q. (2011). "Analysis of the Antecedents of Customer Loyalty of Telecommunication Industry in Ghana the Case of Vodafone (Ghana)," International Business Research,4(1): 1-13.

Bose, R. (2002). "Customer Relationship Management: Key Components for IT
Success," Industrial Management \& Data Systems, Vol. 102/ 2, Pp. 89-97.

Boyle, M. J. (2004). "Using CRM Software Effectively," CPA Journal , Vol. 74 No.7, Pp.17

Bradshaw, D. \& Brash, C. (2001). "Management Customer Relationships in the E-Business World: How to Personalise Computer Relationships for Increased Profitability," International Journal of Retail \& Distribution Management, Vol. 29 No. 12, Pp. 520-30.

Butler, S. (2000). "Changing the Game: CRM in the E-World," Journal of Business Strategy, Vol. 21 No.2, Pp.13-14.

Chan, J. O. (2005). "Toward a Unified View of Customer Relationship Management," the Journal of American Academy of Business, March, Pp. 32-8.

Communications and Information Technology Commission CITC. (2011). "ICT Indicators in the Kingdom of Saudi Arabia (Q3 2011)," PDF Report.

Galitsky, B. \& De La Rosa, J. L. (2011). "Concept-Based Learning of Human Behavior for Customer Relationship Management," Information Sciences 181(10): 2016-2035. http:/ / dx.doi.org/ 10.1016/ j.ins.2010.08.027

Gerpott, T. J. (1998). Strukturwandel des Deutschen Telekommunikationsmarktes, in: Fink, D. and Wilfert, A., Editors, 1998. Handbuch Telekommunikation und Wirtschaft, Vahlen, München, Pp. 49-75.

Ghodeswar, B. M. (2001). Winning Markets Through Effective Customer Relationship Management, in Sheth, J. N., Parvatiyar, A., Shainesh, G. (Eds),Customer Relationship Management: Emerging Concepts, Tools and Applications, Tata Mcgraw-Hill, New Delhi, Pp.71-8.

Harding, D., Cheifetz, D., Deangelo, S. \& Ziegler, E. (2004). "CRM's Silver Lining," Marketing Management, Vol. 13 No.2, Pp.27. 
Hart, C. W. L. (1995). "Mass Customization: Conceptual Underpinnings, Opportunities and Limits," International Journal of Service Industry Management, Vol. 6 No.2, Pp.36-45.

Hsieh, M. H. (2009). "A Case of Managing Customer Relationship Management Systems: Empirical Insights and Lessons Learned," International Journal of Information Management 29(5): 416-419.

ICT Indicators, (2009) Retrieved Http:/ / Www.Itu.Int/ Net/ Pressoffice/ Backgr ounders/ General/ Pdf/ 3.Pdf March 2011

Khatibi, A. A., Ismail, H. \& Thyagarajan, V. (2002). "What Drives Customer Loyalty: An Analysis From The telecommunications Industry,"

Knauer, M. (1995). Kundenbindung in der Telekommunikation: das Beispiel T-Mobil. in: Bruhn, M. and Homburg, C., Editors

Kotler, P. (1997). "Marketing Management: Analysis, Planning and Control," 9th Edition, Englewood Cliffs, Prentice Hall, New York.

Kuusik, A. \& Varblane, U. (2009). "How to Avoid Customers Leaving: the Case of the Estonian Telecommunication Industry," Baltic Journal of Management , 4(1): 66-79.

Lin, R.- J., Chen, R.- H. \& Chiu, K. K.- S. (2010). "Customer Relationship Management and Innovation Capability: an Empirical Study," Industrial Management \& Data Systems, 110(1): 111-133.

Massey, A. P., Montoya-Weiss, M. M. \& Holcom, K. (2001). "Re-Engineering the Customer Relationship: Leveraging Knowledge Assets at IBM," Decision Support Systems, Vol. 32 No. 2, Pp. 155-70.

Mendoza, L. E., Marius, A., María, P. \& Grimán, A. C. (2007). "Critical Success Factors for a Customer Relationship Management Strategy," Information and Software Technology 49(8): 913-945.
Ndubisi, N. O., Wah, C. K. \& Ndubisi, G. C. (2007). "Supplier-Customer Relationship Management and Customer Loyalty: The banking industry perspective,"

Nguyen, T. H., Sherif, J. S. \& Newby, M. (2007). "Strategies for Successful CRM Implementation," Journal of Information Management \& Computer Security Vol. 15 No. 2, 2007 Pp. 102-115

Nunnally, J. C. (1978). Psychometric Theory (2nd Ed.). New York: Mcgraw-Hill.

Payne, A. \& Frow, P. (2005). "The Role of Multichannel Integration in Customer Relationship Management," Industrial Marketing Management, Vol. 33 No. 6.

Pezeshki, V., Mousavi, A. \& Grant, S. (2009). "Importance-Performance Analysis of Service Attributes and Its Impact on Decision Making in the Mobile Telecommunication Industry," Measuring Business Excellence, 13(1): 82-92.

Rigby, D. K., Reichheld, E. F. \& Schefter, P. (2002). "Avoid the Four Perils of CRM," Harvard Business Review, Vol. 80 No. 2, Pp. 101-9.

Saudi Arabia Telecommunications Report, 2011 Retrieved March 2011 Http:/ Www.Citc.Gov.Sa/ English/ Aboutus/ A reasofwork/ Pages/ Default.Aspx

Schierholz, R., Kolbe, L. M. \& Brenner, W. (2007). "Mobilizing Customer Relationship Management," Business Process Management Journal, Vol. 13 No. 6, Pp. 830-852.

Schierholz, R., Kolbe, L. M., Geib, M., Kohnke, O. \& Brenner, W. (2007). "Success Factors in the Introduction of Standard Software in Core Processes of Banks," in Proceedings of the European Conference on Information Systems.

Schoder, D. \& Madeja, N. (2004). “Is Customer Relationship Management a Success Factor in Electronic Commerce?," Journal of Electronic Commerce Research, Vol. 5 No. 1, Pp. 38-53. 
13 Journal of Mobile Technologies, Knowledge \& Society

Sin, L. Y. M., Tse, A. C. B. \& Yim, F. H. K. (2005). "CRM: Conceptualization and Scale Development," European Journal of Marketing, Vol. 39 Nos 11/12, Pp. 1264-90. Stewart Publications 0967-3237

Swift, R. S. (2001). Accelerating Customer Relationships: Using CRM and Relationship Technologies, Prentice-Hall, Englewood Cliffs, NJ.

Uncles, M. D., Dowling, G. R. \& Hammond, K. (2003). "Customer Loyalty and Customer Loyalty Programs," Journal of Consumer Marketing. Vol. 20, No.4, Pp. 294-316.

Valsecchi, M., Renga, F. M. \& Rangone, A. (2007). "Mobile Customer Relationship Management: an Exploratory Analysis of
Italian Applications," Business Process Management Journal , Vol. 13 No. 6, Pp. 755770.

Verhoef, P. C. \& B. Donkers (2001). "Predicting Customer Potential Value an Application in the Insurance Industry," Decision Support Systems 32(2): 189-199.

Winer, R. S. (2001). "A Framework for Customer Relationship Management," California Management Review, Vol. 43 No. 4, Pp. 83-105.

Zablah, A. R., Bellenger, D. N. \& Johnston, W. J. (2004). "Customer Relationship Management Implementation Gaps," Journal of Personal Selling \& Sales Management, Vol. 24 No. 4,Pp. 279-95. 